\title{
Study of the plasma emission in a magnetron sputtering system for a-Si:H production
}

\author{
Estudo da emissão de plasma em um sistema de pulverização catódica \\ para a produção de $a-S i: H$
}

Thiago Moura ${ }^{1,2}$, Miranda, D.O ${ }^{1,2}$, Guimarães, G.R. ${ }^{1,2}$, Fadgen, W. J. ${ }^{1}$, Branco, J.R.T. ${ }^{1,2}$

\begin{abstract}
The use of hydrogenated amorphous silicon, a-Si:H, for solar cell applications has shown interesting possibilities for increasing the efficiency of heterojunctions and reducing the cost of solar cells. Hydrogen incorporation in thin films of amorphous silicon is crucial for obtaining good electrical properties because it passivates the dangling bonds in the structure. The study of several parameters that influence the formation of films is necessary in order to optimize the material properties. In this paper, the optical emission of plasma during film growth by sputtering was studied in order to evaluate the hydrogenation process, with varying levels of hydrogen in a H-Ar plasma. The results show the possibility of controlling the process through optical emission spectroscopy (OES) without the need to introduce further analytical tools in the reactors.
\end{abstract}

Keywords: Plasma; Sputtering; Si:H; Optical Emission Spectroscopy.

\section{Resumo}

A utilização de silício amorfo hidrogenado, a-Si:H, para aplicações em células solares tem mostrado interessantes possibilidades para aumentar a eficiência de heterojunções e reduzir o custo de células solares. A incorporação de hidrogênio em filmes finos de silício amorfo é crucial para a obtenção de boas propriedades elétricas, pois este passiva as ligações pendentes na estrutura. O estudo de vários parâmetros que influenciam a formação de filmes é necessário a fim de optimizar as propriedades do material. Nesta pesquisa, a emissão óptica do plasma durante o crescimento do filme por pulverização catódica foi estudada com a finalidade de avaliar o processo de hidrogenação, com diferentes niveis de hidrogênio em um plasma $H$-Ar. Os resultados mostram a possibilidade de controlar o processo através de espectroscopia de emissão óptica (EEO), sem a necessidade de introduzir novas ferramentas analíticas nos reatores.

Palavras-chave: Plasma; Pulverização catódica; Si:H; Espectroscopia de Emissão Ótica. 


\section{Introdução}

In recent decades, energy generation through the use of solar power has been emerging as a significant and competitive supplier to the world's electricity market. The generation of energy from solar radiation is becoming a mature technology, but its high cost limits its widespread use. Efforts have been made to make the technology more accessible, especially in developing countries like Brazil, and also to achieve more cost-efficient devices. One example of these devices is a heterostructure based upon the junction of an amorphous silicon layer grown on crystalline silicon with an intrinsic a-Si:H layer between the p-n layers. This kind of solar cell has been cited in the literature with an efficiency of above $20 \%{ }^{1,6}$. The use of amorphous silicon (a-Si) as an emitting layer in photovoltaic cells reduces production costs because it can be produced at lower temperatures compared to crystalline silicon $(\mathrm{c}-\mathrm{Si})^{(1)}$.

In pure a-Si, there is a large concentration (about $10^{21}$ per $\mathrm{cm}^{3}$ ) of defects known as dangling bonds in the lattice structure. One way to reduce these defects is to passivate them with hydrogen ${ }^{(2)}$ which reduces the defect density from about $10^{21} \mathrm{~cm}^{3}$ to $1015-1016 \mathrm{~cm}^{3}$, which in a-Si:H represents less than one dangling bond per million silicon atoms ${ }^{(3)}$. Hydrogen plays an important role in the passivation of defects. The understanding of the incorporation and stability of hydrogen in a-Si:H has led to intensive research ${ }^{1}$.

In this work we used the technique of optical emission spectroscopy to evaluate the behavior of active species in plasma sputtering with $\mathrm{Ar}+\mathrm{H}_{2}$ gases that are indicative of hydrogen incorporation in the a-Si:H thin films. The results show that hydrogen incorporation can be related to the plasma optical emission lines of $\mathrm{SiH}$, and that thin films with high hydrogen percentages have been achieved.

\section{Experimental}

The experiments were performed in a vacuum chamber, a Balzers BAS 450 PM, that uses magnetron sputtering. The plasma atmosphere gases were $\mathrm{Ar}+\mathrm{H}_{2}$.
The substrate temperature was fixed at $100^{\circ} \mathrm{C}$ and the base pressure of the chamber was $9 \times 10^{-7} \mathrm{mbar}$ with a working order of $10^{-4} \mathrm{mBar}$. Table 1 shows some of the process parameters of the experiments:

Table 1. Parameters used in the sputter plasma generation.

\begin{tabular}{c|c|c|c|c|}
\hline $\begin{array}{c}\text { Power } \\
(\mathbf{W})\end{array}$ & $\begin{array}{c}\text { Base } \\
\text { pressure } \\
(\mathbf{m b a r})\end{array}$ & $\begin{array}{c}\text { Temperature } \\
\left({ }^{\circ} \mathbf{C}\right)\end{array}$ & \multicolumn{2}{|c|}{ Flow range (sccm) } \\
\hline 150 & & & $\mathrm{Ar}$ & $\mathrm{H}_{2}$ \\
\hline 300 & $9 \times 10^{-7}$ & 100 & $75-22.5$ & $0-52.5$ \\
\hline 450 & & & & \\
\hline
\end{tabular}

The analysis of the optical emission of the plasma was carried out using a EP200Mmd from Verity Instruments with a diffraction grating with grooves and holographic blaze angle whose spectral range is between 200 and $900 \mathrm{~nm}$. The plasma was studied under the following conditions: first, by varying the flow rate of the two gases, and in the second case by keeping the Ar flow constant and varying only the hydrogen flow rate. We also studied the effect of the power used to generate the plasma on the line emission intensity for each species, by varying it between 150,300 and $450 \mathrm{~W}$.

In order to calculate the hydrogen percentage in the thin film we used the infrared spectroscopy technique, through which it is possible to determine the percentage of hydrogen bonded in the a-Si:H structure. The process consists of calculating the area between the stretching modes for SiHx $\left(2000-2100 \mathrm{~cm}^{-1}\right)(\text { Eq. } 1)^{(4)}$ :

$$
S=\int \frac{\alpha(\omega)}{\omega} d \omega
$$

where the absorption coefficient a is obtained using the intensity ratio for a given thickness $d$ :

$$
\alpha=\frac{1}{d} \ln \left(\frac{I_{0}}{I} \dot{\dot{j}}\right)
$$

Then the sample density in the substrate is:

$$
N_{x}=A_{w} S
$$

where $N \mathrm{x}$ is the film density and $A \mathrm{w}$ is a proportionality constant found in the literature. 
Using these expressions we can calculate the hydrogen percentage formula by means of ${ }^{(4)}$ :

$$
c_{x}=\frac{N_{x}}{\left(N_{S}+N_{x}\right)}
$$

where $c_{x}$ is the percentage of the material in the film and $N_{\mathrm{s}}$ is the substrate density.

\section{Results and Discussion}

We monitored the main peaks in order to infer information about the process of hydrogenation of amorphous silicon films, namely the peaks ArI $4 p-4 s, H \alpha(n=3)$, $\mathrm{H} \beta(\mathrm{n}=4)$ and $\mathrm{SiH}$ A $2 \Delta-\mathrm{X} 2 \Pi$. Figure 1 shows the spectrum in the range between 300-850 nm and Fig. 2 shows the evolution of mains peaks with the variation of the Ar percentage in which a maximum point in the curve of $\mathrm{SiH}$ at around $50 \% \mathrm{Ar}$ can be observed, which indicates a greater number of active species, as predicted in literature ${ }^{(5)}$.

Figure 3 shows the evolution of the peaks while keeping the Argon flow fixed at $22.5 \mathrm{sccm}$ and varying the $\mathrm{H}_{2}$ flow from 0 to $75 \mathrm{sccm}$ in steps of $7.5 \mathrm{sccm}$. From the graph we can see an upward trend in the $\mathrm{SiH}$ optical line. In 1980, Matsuda reported that in proportions with much more $\mathrm{H}_{2}$, the $\mathrm{SiH}$ line emission tends to break off ${ }^{(5)}$, but this limit is impossible to reach in our system due to the saturation of the cryogenic vacuum pump when large quantities of $\mathrm{H}_{2}$ are injected.

This upward trend in the $\mathrm{SiH}$ optical line led to varying both gases to study the relation between the

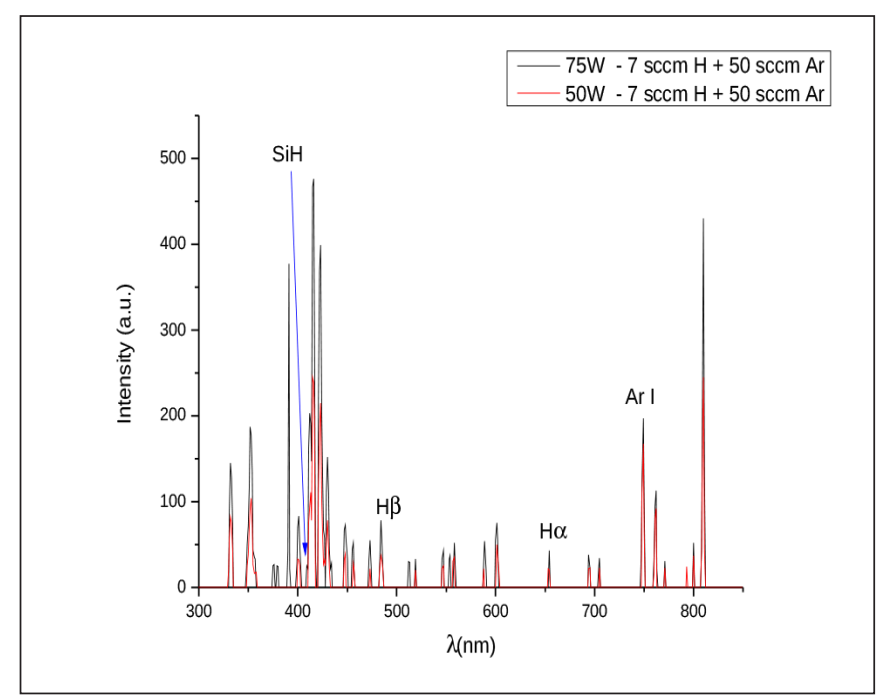

Figure 1. Optical emission spectrum in an $\mathrm{Ar}+\mathrm{H} 2$ atmosphere. optical line emission from the plasma and the hydrogen incorporation in the film.

The effect of the power source in the behavior of the optical emission lines was observed for the case in which both gases vary. Figure 4 shows the changes in intensity for different gas percentages and power source used in the system. The relevant effect of power source on the intensity can be also observed.

Figure 5 shows the rate of variation of the optical emission intensity for the data presented in Fig. 4. The idea of these graphs is to analyze the "speed" with which the emission intensity varies for each percentage of gas and energy

For each power level the behavior of the curves are similar. Intensity variation is greater for the greater power levels as might be expected from the analysis of the graphs

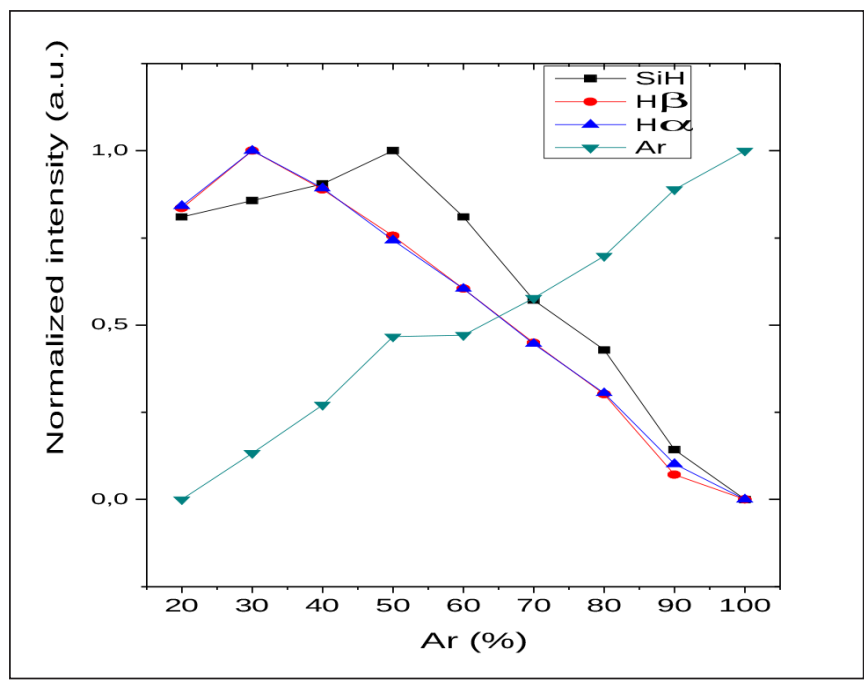

Figure 2. Evolution of the normalized optical emission lines with the $\mathrm{Ar}-\mathrm{H}_{2}$ concentration in the process for $300 \mathrm{~W}$.

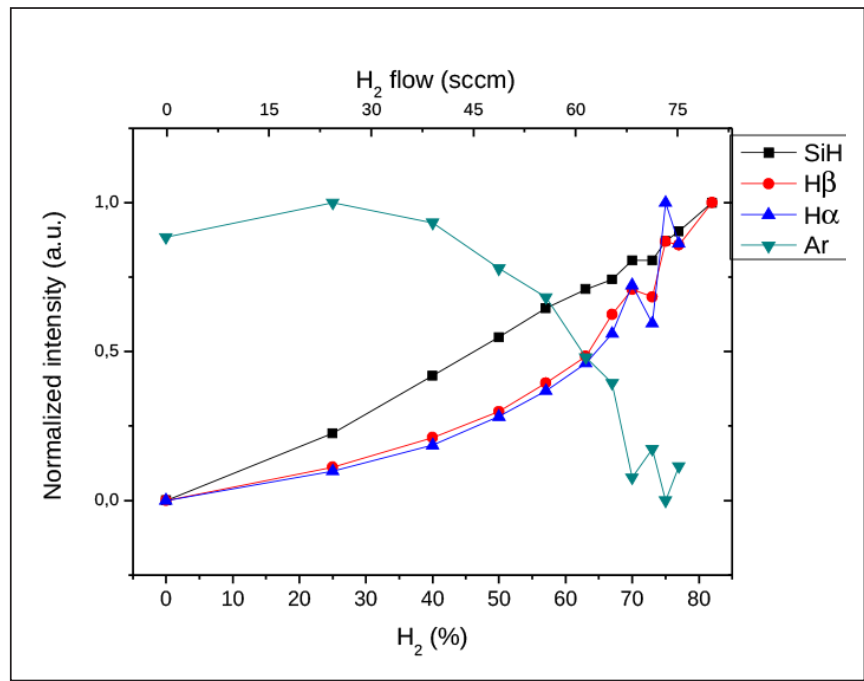

Figure 3. Evolution of the normalized optical emission lines keeping the Ar flow Constant and varying the $\mathrm{H}_{2}$ flow. 
in Fig. 4. Only the behavior of the curve for $\mathrm{SiH}$ has a small difference from the others. It is noted that below $50 \%$ Ar the variation of the Power source of $300 \mathrm{~W}$ becomes greater than for a power of $450 \mathrm{~W}$ and the variation the $150 \mathrm{~W}$ curve is much lower compared to the others. These are important indicators for the production of films of a-Si:H as reported by Matsuda in which the points of greatest emission intensity of $\mathrm{SiH}$ lead to higher rates of $\mathrm{H}$ bonded to the structure of amorphous $\mathrm{Si}$, which consequently passivate more dangling bonds. Table 2 and Fig. 7 show the variation in the percentage of hydrogen for each parameter setting. These results show that films with higher percentage of hydrogen in its structure are those with a $50 \% \mathrm{H}_{2}$ atmosphere composition. Comparing the optical emission evolution that was obtained the highest emission intensity for the $\mathrm{SiH}$ with $50 \% \mathrm{H}_{2}$ atmosphere composition we can find a pattern of equivalent behavior. Only one sample with composition of $40 \% \mathrm{H}_{2}$ does not have the desired quality. But it is important to consider that the power source was in the upper range limit.

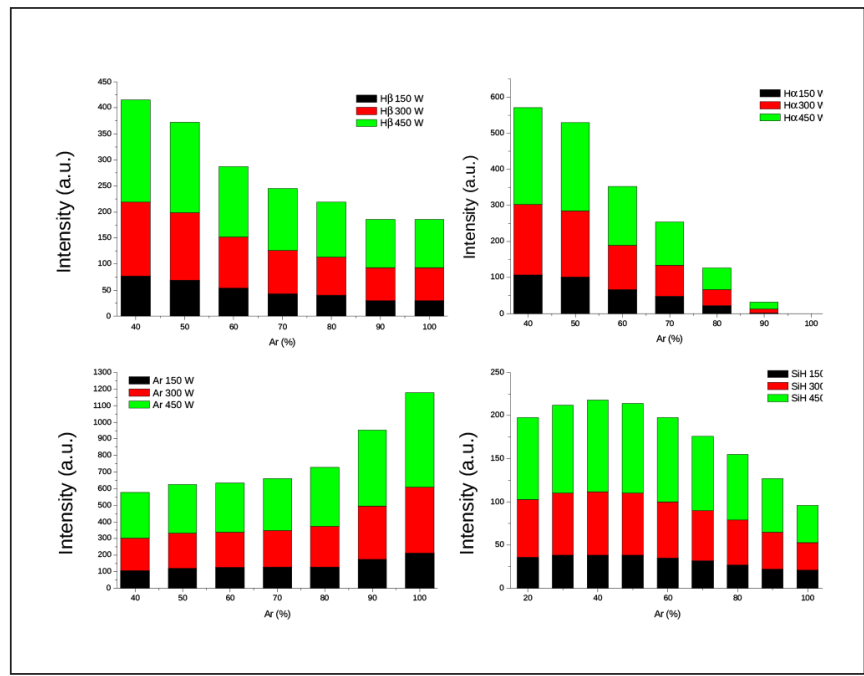

Figure 4. Effect of power on the intensity of the $\mathrm{H} \alpha$, $\mathrm{H} \beta$, Ar e $\mathrm{SiH}$ peaks.

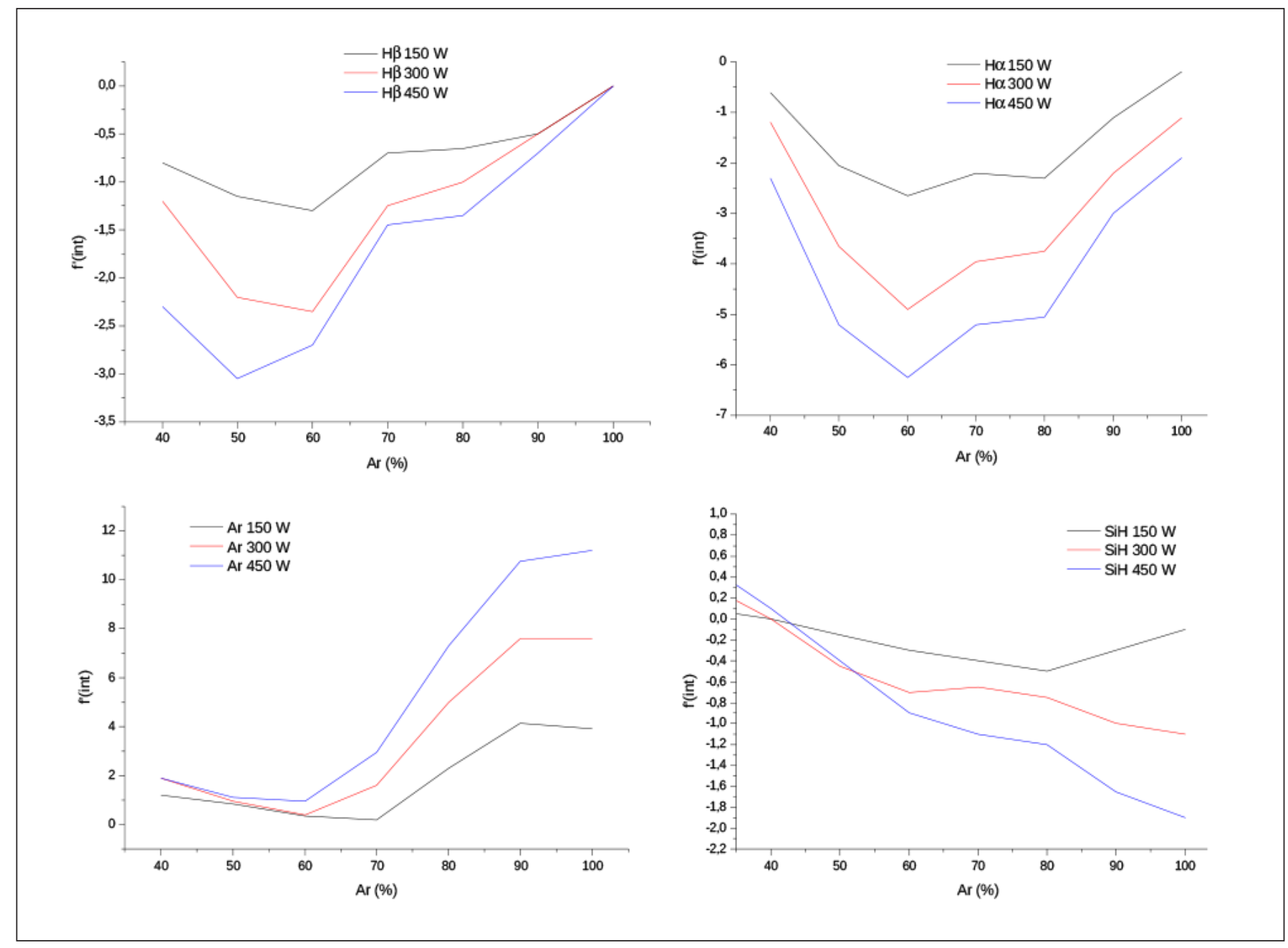

Figure 5. Intensity derivation. 
Table 2. Hydrogen percentages in the film structure for each setting parameter.

\begin{tabular}{c|c|c|c|c|}
\hline Sample & $\begin{array}{c}\text { Power } \\
(\mathbf{W})\end{array}$ & $\begin{array}{c}\text { Flow } \mathbf{H}_{\mathbf{2}} \\
(\mathbf{\%})\end{array}$ & $\begin{array}{c}\text { Thickness } \\
(\mathbf{n m})\end{array}$ & $\begin{array}{c}\mathbf{\%}_{\mathbf{2}} \mathbf{i n} \\
\text { the film }\end{array}$ \\
\hline 1 & 150 & 60 & 220 & 17,09 \\
\hline 2 & 450 & 40 & 90 & 26,31 \\
\hline 3 & 300 & 50 & 121 & 28,04 \\
\hline 4 & 150 & 40 & 77 & 17,19 \\
\hline 5 & 300 & 50 & 124 & 25,55 \\
\hline 6 & 300 & 50 & 122 & 25,28 \\
\hline 7 & 450 & 60 & 192 & 19,14 \\
\hline
\end{tabular}

The Raman shift of all samples is presented in Fig. 6. The peak at $520 \mathrm{~cm}^{-1}$ which is related to the crystalline fraction in thin films of silicon is not present and one only observes the band related to the amorphous phase, adjacent to crystalline peak. For the three repeated measurements carried out at the central point of the parameters, i.e, $50 \% \mathrm{H}_{2}$ and $300 \mathrm{~W}$, there was a variability of $5.79 \%$.

Figure 7 illustrates these results considering only the percentage of hydrogen in the atmosphere of the plasma and the hydrogen percentage incorporated in the film. It is possible to see the behavior mentioned above with only one point which does not have the desired behavior. This may be due to the high power used for this case. It is possible to note that due to the expectation that the sputtering yield for these gases will increase for higher power sources, the same percentage of gas would thus lead to a higher state of excitation of $\mathrm{H}$, thus permitting greater grouping with Si due to the effect of the Ar.

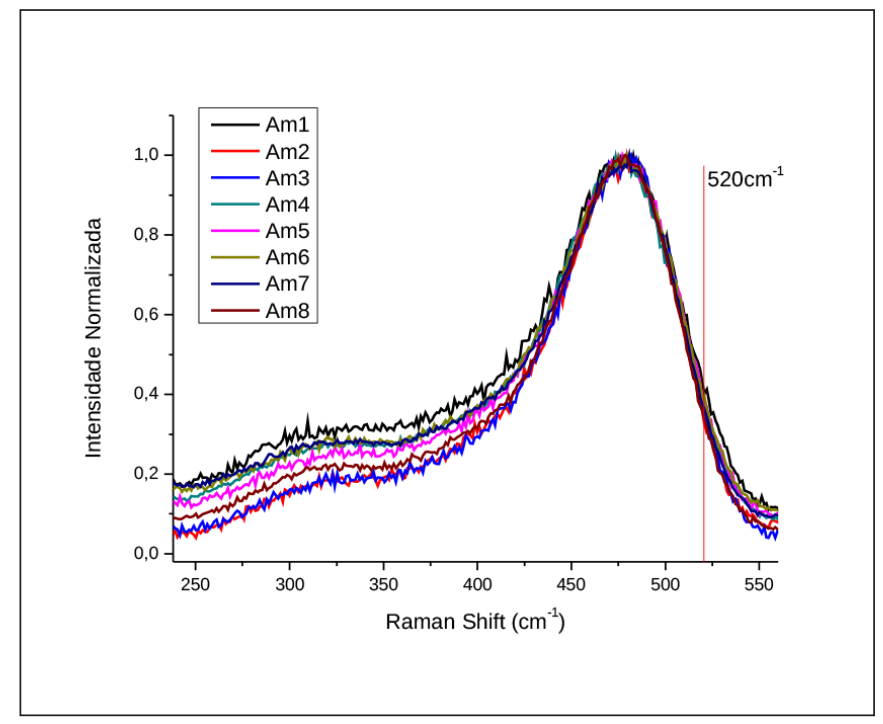

Figure 6. Raman shift spectrum of all a-Si:H samples.

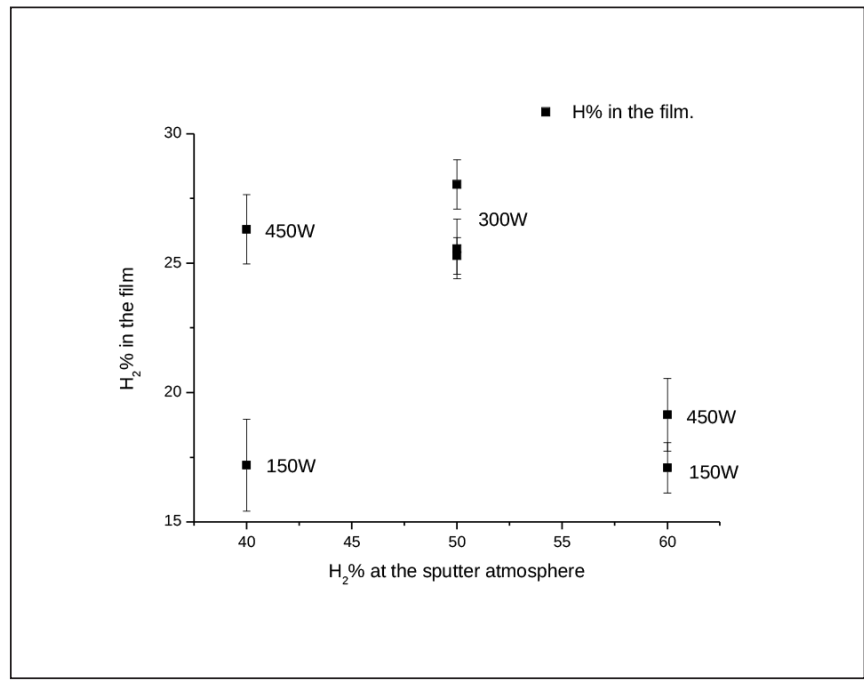

Figure 7. Incorporation of hydrogen in the film as a function of $\mathrm{H}_{2}$ percentage in the plasma atmosphere.

\section{Conclusions}

A sputtering process that allows very high $\mathrm{H}$ content in the a-Si:H has been implemented. The study showed that monitoring of plasma species is effective in predicting the level of hydrogenation of a-Si. It is also shown that maximum hydrogenation is a function $\mathrm{H}$ content as well as sputtering power and that there is a optimum level of $\mathrm{H}$ dilution in the $\mathrm{H}-\mathrm{Ar}$ plasma, that corresponds to its the maximum level of $\mathrm{SiH}$ species. It is also shown that the $\mathrm{H}$ content for this optimum dilution as well as the level of film hydrogenation increases with sputtering power. Finally it is shown that the effects of changing process variables on the hydrogenation can be monitored by the optical emission from plasma, which makes this technique a potential tool to control the production of a-Si:H.

\section{Referências}

1. Tanaka, M., Okamoto, S. Tsuge, S., Kiyama, S. Development of HIT Solar Cells with more than 21\% conversion efficiency and commercialization of highest performance HIT Modules. 3rd World Conference on Photovoltaic Energv Conversion, Osaka-Japan, May 11 - 18, 2003.

2. Burrows, M. Z., Das, U. K., Opila, R. L., De Wolf, S., Birkmire, R. W. Role of hydrogen bonding environment in aSi:H films for c-Si surface passivation. J. Vac. Sci. Technol. A $26,4 \ldots$, Jul/Aug 2008. 
3. Poortmans, Jef And Arkhipov, Vladimir,(editors). Thin Film Solar Cells Fabrication, Characterization and Applications. John Wiley \& Sons Ltd, 2006.

4. Saleh, R., L. Munisa, And W. Beyer, The Infrared Absorption Strength of Si-H Stretching and Wagging Modes of the Amorphous Silicon Carbon (a-SiC:H) Films Produced by DC Sputtering Methods. Phys. J. of the Indonesian Phys. Soc., 2002. A5(0210): p. 0210-1 0210-4.
5. Matsuda, A., Nakagawa, K., Tanaka, K, Matsumura, M. Plasma spectroscopy - control and analises of a Si:H deposition. J. of Non-Cryst. Sol. 35 a 36 (1980) 183-188

6. Taguchi, Mikio, Sakata, Hitoshi, Yoshimine, Yukihiro, Maruyama, Eiji, Terakawa, Akira and TANAKA, Makoto. An approach for the higher efficiency in the hit cells. Photovoltaic Specialists Conference, Conference Record of the Thirty-first IEEE 2005. 